\title{
References:
}

1. Арноль И.В. (2002) Стилистика. Современный английский язык: Учебник для вузов. 384.

2. Гуцуляк I.Г. (2005) Мовостиль українського поетичного бароко. Вилучено 3: http://irbis-nbuv.gov.ua/ASUA/0078994

3. Корольова В.В. (2017) Сучасний український драматургійний дискурс: комунікативна структура та прагматика. 423.

4. Лотман Ю. (1996) Текст у тексті. 428-441.

5. Сахарова О.В. (2015) Реконструкція мовної особистості в драматургічному дискурсі. Система і структура східнослов'янських мов, (8), 197-207. Вилучено 3: http://nbuv.gov.ua/UJRN/sissm_2015_8_29

6. Синявська Л.I. (2019) Українська драматургія кінця XIX - початку XX століття: комунікативні стратегії. 302.

7. Яусс X.P. (1995) История литературы как провокация литературоведения. С. 34-84.

DOI https://doi.org/10.30525/978-9934-26-073-5-2-16

\section{ПРИНЦИПИ УКЛАДАННЯ КОМУНІКАТИВНОГО ДОВІДНИКА ДЛЯ СОЦІАЛЬНОЇ ВЗАЕМОДІЇ}

\author{
Пелепейченко Л. М. \\ доктор філологічних наук, професор, \\ професор кафедри філології, перекладу та стратегічних комунікачій \\ Начіональної академії Національної гвардії Украӥни \\ м. Харків, Україна
}

Необхідність укладання комунікативного довідника для широкого використання продиктована самим життям і проблемами соціальної комунікативної взаємодії, свідком яких нам доводиться бути протягом останніх років. Доволі часто користувачі Інтернету вимушені відчувати когнітивний дисонанс, спостерігаючи за тим, які приголомшливі заяви роблять представники владних структур у спілкуванні з громадянами, які помилки міжкультурної комунікації вони допускають під час офіційних візитів до інших країн. Здавалось би, високий соціальний статус представників влади, їхня освіченість, інтелектуальність, найкращі моральні якості мали б забезпечити успішність комунікації в будь-якій ситуації проте реальні факти часто не відповідають очікуванням громадськості. Однією з причин названих суперечностей є відсутність лексикографіч- 
них джерел, які б могли популяризувати серед широкого загалу знання про механізми комунікації. Отже, актуальним стає питання про створення таких видань та принципи їх укладання. 3 огляду на те, що загальні закономірності комунікації дещо по-різному проєктуються на взаємодію в різних галузях діяльності, виникає необхідність обмежити аналіз зазначеного питання сферою діяльності. У роботі, яка представлена в цих тезах, розглядається питання про принципи укладання комунікативного довідника для соціальної взаємодії.

На сьогодні в Україні створені комунікативні довідники та навчальні посібники, які можуть слугувати в організації публічної комунікації, доборі форм і методів взаємодії органів місцевого управління 3 громадськістю [1; 2]. У них представлено цінні практичні поради стосовно нормативних та правових засад здійснення контактів із громадянами в різних ситуаціях, комунікації з представниками ЗМІ i т. ін. I все ж питання про створення довідника, який би забезпечував дотримання вимог до комунікації, розроблене недостатньо і потребує спеціальної уваги.

Мета цієї роботи - обгрунтувати принципи укладання комунікативного довідника для соціальної взаємодії в межах країни та контактів 3 представниками інших держав.

У науковій літературі добре обгрунтовані принципи укладання словників [3], а отже, деякі надбання в галузі словникової справи можна частково перенести і на довідники. Так, лексикографи завжди наголошували на необхідності орієнтації словників на потреби користувача. Найбільш повно назване питання розкрито в працях Р. Хартмана, який обгрунтував 12 основних принципів, що репрезентують спрямування на користувачів [3, с.102-103]. Запропоновані вченим принципи доцільно взяти до уваги і в укладанні комунікативного довідника для соціальної взаємодії. Орієнтування на потреби користувача інтерпретуємо як один із основних принципів укладання обраного в цій праці довідника. Другий основний принцип - необхідність урахування специфіки соціального дискурсу. Із основних принципів випливають і ознаки, які доцільно враховувати в процесі роботи: необхідність уявляти собі свого читача [3, с. 102], рубрики довідника створювати відповідно до видів дискурсивних практик користувачів у соціальних комунікаціях, а в інформації рубрик відтворювати фактори, що забезпечують успішність комунікації.

Для створення уявлення про користувача комунікативного довідника вважаємо за доцільне взяти до уваги такі аспекти, як зайнятість користувача та потреба в отриманні інформації про фактори успішної 
комунікації. За викладеними аспектами в нашій роботі були змодельовані характеристики типового користувача, які потім проєктувались на ознаки вже самого довідника. Наведемо створений нами уявний портрет сучасного користувача. Адресат довідника - особа, яка за родом своєї діяльності (керівник організації, управлінець, представник владних чи законодавчих структур, журналіст - автор текстів новин) має спілкуватись із громадянами в процесі безпосередніх публічних зустрічей чи через канали зв'язку (ЗМІ, гарячі телефонні лінії, прямий телевізійний ефір, соціальні мережі), відповідати на запитання громадян (часто доволі гострі), давати інтерв'ю представникам ЗМІ чи викладати в Інтернет меседжі з новинами - друковані або у формі відеороликів. Для успішності соціальних комунікацій у будь-яких ситуаціях користувачеві довідника важливо вміти відповідати на гострі, болісні запитання, не порушуючи етичних норм спілкування. Отже, довідник має забезпечити відбір інформації, необхідний і достатній для досягнення успіху в будьяких умовах комунікації, в тому числі і складних. Автор новин повинен уміти подавати інформацію, забезпечуючи лаконічність, повноту, достовірність та ясність викладення змісту. Звідси випливає необхідність відтворення в довіднику ознак, що забезпечують досягнення якісного викладення інформації. Адресат довідника - людина, яка має багато інших соціальних завдань, тому вкрай обтяжена часом. Проєктуємо цю інформацію на ознаки довідника: слід забезпечити зручність у користуванні, простоту доступу до інформації, лаконічність іiі викладення. У процесі професійної діяльності користувачеві довідника доводиться іноді (можливо, й часто) виїжджати в закордонні відрядження до різних країн. Із цього випливає, що в довіднику має бути подана інформація з міжкультурної комунікації. Відштовхуючись від викладеної інформації, формулюємо допоміжні принципи укладання довідника для соціальних комунікацій, які конкретизують основний: зручності в користуванні; простоти доступу до інформації; лаконічності; принцип когнітивно-прагматичних опор [4, с. 191]. Зручність у користуванні була врахована у виборі тематичного принципу до структурування статей довідника. Алфавітний принцип $є$ зручним для користувача, що вже знає, яке слово він бажає знайти, тобто, про що саме він хотів би довідатись; тематичний - для користувача, якого цікавить тема, що розкриває ті чи інші фактори успішної комунікації. На нашу думку, в укладанні довідника слід надати перевагу тематичному принципу, а в алфавітному показнику представити основні терміни та поняття із зазначенням сторінок, на яких вони подані. Способом реалізації принципу когнітивних опор вважаємо врахування в структурі 
та змісті статей довідника типів дискурсивних практик у соціальній взаємодії. 3 огляду на викладені вище типи дискурсивних практик користувача структура довідника має включати такі рубрики: «Умови якісного викладення інформації», «Створення морального клімату комунікативної взаємодії», «Успішність міжкультурної комунікації».

У розділі «Умови якісного викладення інформації» доцільно подати такі типи інформації: максими комунікації за концепцією Г.П. Грайса [5, с. 45-47] (спроєктувавши їх на дискурс соціальної комунікативної взаємодії); закони подавання інформації; перешкоди в сприйнятті інформації. Оскільки постулати кожної із максим Грайса зорієнтовані на комунікацію загалом (переважно міжособистісну та публічну) доцільно спроєктувати їх на соціальну сферу контактів, взявши до уваги помилки, які були допущені в реальній соціальній взаємодії. Розділ «Створення морального клімату комунікативної взаємодії» має представляти інформацію про максими комунікації за концепцією Дж. Ліча [6, с. 15-18], спроєктувавши ії на соціальну сферу контактів. До цього ж розділу доцільно включити статтю, яка б стисло повідомляла про комунікативні стратегії, що забезпечують взаєморозуміння в комунікації. В обох тематичних розділах вважаємо за необхідне помістити рубрику «Помилки i табу комунікації». Мета третього тематичного розділу, що присвячений успішності міжкультурної комунікації, - познайомити користувачів із типами комунікативних культур, їхніми основними цінностями, особливостями комунікативних стилів, факторами, які можуть спричинити міжкультурні непорозуміння чи конфлікти. Рубриці «Помилки і табу міжкультурної комунікації» в цьому розділі слід приділити особливу увагу, змоделювавши ії не тільки на основі інформації з теоретичних джерел, а й на прикладах найбільш поширених помилок, що траплялися в реальній діяльності, - вони достатньо представлені в мережі Інтернету. Зауважимо, що оприлюднювати прізвища осіб, які допускали помилки, вважаємо неетичним, а отже, зайвим.

Узагальнюючи викладене, назвемо основні та підпорядковані їм принципи довідника для соціальної комунікативної взаємодії. Основними є два принципи: орієнтованість на потреби користувача і врахування їхніх дискурсивних практик; допоміжними - зручності в користуванні; простоти доступу до інформації; лаконічності; а також принцип когнітивних опор.

Створення комунікативного довідника для соціальної сфери контактів за схарактеризованою концепцією розглядаємо як перспективу розроблення заявленої теми. 


\title{
Література:
}

1. Боцюрків М., Коник Д., Головенко Р. Комунікація органів місцевого самоврядування: практичний довідник для посадових осіб. URI: https://cutt.ly/zvkMfZH.

2. Дрешпак В. М.Д73 Комунікації в публічному управлінні: навч. посіб. Дніпро: ДРІДУ НАДУ, 2015. 168 c. URL: https://cutt.ly/fcXzFAV.

3. Hartmann R.R.K. Sociology of the Dictionary User: Hypotheses and Empirical Studies: W.D.D., 1989. V. 1 P. 102-111.

4. Пелепейченко Л.М. Фактор адресата у виборі принципів укладання двомовних словників. Украӥнська і слов'янська тлумачна та перекладна лексикографія. Леонідові Сидоровичу Паламарчукові / Інститут української мови НАН України; відп. ред. І.С.Гнатюк. К.: КММ, 2012. C. $186-192$.

5. GRICE H. P. Logic and conversation. In P. Cole and J. Morgan (eds) Studies in Syntax and Semantics III: Speech Acts. New York: Academic Press, 1975. P. 41-58. URI: https://cutt.ly/XvkNRE2.

6. LEECH G. Principles of Pragmatics. London, New York: Longman, 1983. 134 p. URI: https://cutt.ly/3vi8jzu.

DOI https://doi.org/10.30525/978-9934-26-073-5-2-17

\section{PROJECTIONS OF COGNITIVE AND ECOLOGICAL LINGUISTICS}

\author{
Prihodko A. I. \\ Doctor of Philological Sciences, \\ Professor at the Chair of English Philology \\ Zaporizhzhia National University \\ Zaporizhzhia, Ukraine
}

The anthropocentric and eco-centric lines may be distinguished as competitive modes in the development of modern humanitarian sciences for the reason that they introduce different approaches to investigating processes and results of human activity. Modern stage of linguistics is characterized by coordination of various scientific opinions, regarding its object - language. With all the differences in the interpretation of natural language dominant directions converge that this phenomenon can be understood and explained only by considering it as an integral part of the cognitive system, i.e. all of the 